\title{
Comparison for the Efficacy of Column Purified Fractions of Sinna occidentalis and Moringa oleifera against Bulinus globosus (Intermediate Host of Schistosoma haematobium) from Goronyo and Shagari Dams, Sokoto State, Nigeria
}

\author{
J. Suleiman, M. T. Muhammad, S. Y. Lema, and A. Abdullahi
}

\section{ABSTRACT}

Introduction: Although, used of molluscicides to control the intermediate host of schistosomes is the best method of choice to control the spread of the snail fever among the people, synthetic molluscicides widely used are cost effective, not available and toxic to the aquatic lives and people that are completely or partially dependents on rivers or lakes water for their everyday supplement.

Aim: this research was aimed at investigation and comparison for the molluscicidal efficacy for $S$. occidentalis and $M$. oleifera leaves extracts against B. globosus (intermediate host of Schistosoma haematobium).

Methodology: Each of the plant was grinded into powder and purified through column using different solvents, $B$. globosus snails were collected from Shagari and Goronyo dams; we identified the animal using chart initially, later on the animals were confirmed as $B$. globosus by malacologist from Ahmadu Bello University Zaria, Nigeria; the Molluscicidal efficacy of the plants was tested against $B$. globosus and compared according to world health organization guidelines; mortality was calculated using Abbort's formula and analysis of variance (ANOVA) was used to determine if there is significant different between the mean mortality at $P \leq 0.05$; qualitative Phytochemical analysis was conducted to determine the chemicals presence in each plant and their combination.

Results: Present study reviled that fractions of the leaves combination showed significantly higher mortality of $B$. globosus in the present study followed by Fractions of $S$. occidentalis then that of $M$. oleifera. For the plants combination, extracts purified using methanol are highly toxic followed by fractions purified using hexane, then ethyl acetate fractions and least Molluscicidal potential was recorded in the fractions obtained using ethanol. S. occidentalis fractions of hexane were highly toxic followed by fractions of methanol, then fractions of ethyl acetate and least mortality was recorded from the fractions of ethanol. Similarly, for the $M$. oleifera, it was observed that, fractions of Methanol were highly toxic followed by hexane fractions then ethanol fractions and least mortality was observed in the fractions of ethyl acetate.

Conclusion: Column purified fractions for the combination for two plants leaves were highly potent for the control of $B$. globosus followed by S. occidentalis then M. oleifera.

Keywords: Bulinus globosus; Comparison; Moringa oleifera; Purified; Sinna occidentalis.

\section{INTRODUCTION}

Schistosomiasis also called snail fever or Bilharziasis was considered among the major diseases neglected in tropical regions, caused by flukes belonging to phylum Platyhelminthes, class; trematoda and genus Schistosoma
Published Online: November 5, 2020 ISSN: $2684-5199$

DOI : $10.24018 /$ ejbio.2020.1.6.45

\section{J. Suleiman*}

Department of Biological Sciences, Sokoto State University, Sokoto, Nigeria.

(e-mail: jafarunsuleiman@ ${ }^{\circledR}$ gmail.com)

\section{T. Muhammad}

Department of Biological Sciences, Sokoto State University, Sokoto, Nigeria.

(e-mail: musasifawa05@gmail.com)

\section{S. Y. Lema}

Department of Biological Sciences, Sokoto State University, Sokoto, Nigeria.

(e-mail: yahayalema@yahoo.com)

\section{A. Abdullahi}

Department of Biological Sciences, Sokoto State University, Sokoto, Nigeria. (e-mail: adamgad83@gmail.com)

*Corresponding Author
[1]. Five different Schistosoma species were identified to cause Schistosomiasis infections [2]. Species of Schistosoma haematobium and Schistosoma mansoni occurred highly in the Africa, the South America, the Middle East and the west India whereas Schistosoma japonicum species are found in the Republic of China, the Indonesia and the Philippines 
while Schistosoma mecongi and Schistosoma intercalatum are found in the Mekong River of South East Asia, the Middle Africa and West African parts of the world [3].

Genera of Bulinus and Biomplaria snails are known to transmit the infective stage (Cercaria) of Schistosomiasis, and infections with schistosomes are characterized by itchy, skin rash (swimmer's itch) and local swelling which can starts about $24 \mathrm{hrs}$ after the initial infection and lasts for about 4 days [4]. Infected individuals may have fever, enlarged liver and spleen, lymph nodes and eosinophilia but this illness usually lasts for one to three weeks [5]. After months or years, infected individuals may experience painful or difficult urination (dysuria), blood in urine (hematuria), urethral obstruction, kidney damage as a result of urine obstruction (obstructive nephropathy), and enlargement of penis [6], [7].

Although schistosomiasis infection is highly increasing during rainy season [8], many human activities such as passing excreta by infected individual in a fresh water, construction of irrigation channels, dams and flood irrigation of crops increased infection with schistosomes in the country [9], [10].

Snail's fever affects over two hundred and forty million $(240,000,000)$ people worldwide, many children and young adults are at greater risk in the tropics and subtropics region [11]. Over $90 \%$ of the infection occurs in sub-Saharan Africa and almost 300,000 people die annually [12], [13]. The highest prevalence of this infection is seen in Nigeria (29 million), which is closely followed by United Republic of Tanzania (19 million) then Ghana and Democratic Republic of Congo (15 million) making up the top five countries in Africa with Schistosoma infection [14].

Although, from Nigerian states, the most infected group is the children, everybody else is at greater risk of contracting the disease if in contact with infested water [15]. Epidemiological survey on urinary schistosomiasis in selected schools of Minna, Niger state revealed that, $12.9 \%$ children were infected [16]; $17.8 \%$ people were infected in Kano State [17]; $19.0 \%$ people in Ebonyi central of Ebonyi State were infected [18]; [19] reported that, 30.5\% people were infected in Kefi town of Nasarawa State and $46.6 \%$ individuals were infected from Ogbadibo Local Government Area, Benue State [20].

Despite the fact that, In the year 2012, the Federal Mnistry of Health (FMH) reported that schistosomiasis has been completely mapped out of Nigerian states (Zamfara, Kwara, Ekiti, FCT, Ondo, Gombe, Ogun, Enugu and Sokoto) [21], there are re-emergence of this diseases in some areas of these states, as preliminary study on occurrence of schistosomiasis conducted among people in Abarma Village of Gusau Local Government of Zamfara in which $74.0 \%$ were found infected [22]; moreover, Singh and [23], reported $60.8 \%$ children in some riverine areas of Sokoto were infected with schistosomiasis.

Although, among the current methods of the control of Schistosomiasis infections are reduction of morbidity and elimination through integrated measures for the control of intermediate hosts of schistosomiasis [24], synthesized chemical molluscicides used for such method were hazardous to the aquatic lives and human health [25], [26]. Due to toxic nature of synthetic molluscicides there are needs to determine the best control methods of Schistosomiasis in order to reduce spread of the disease [27]. Moreover, in the environment like as Shagari and Goronyo where majority of the people are dependents on fresh water bodies (lakes, rivers and dam), it is highly dangerous to use synthetic molluscicides for the control of intermediate host of schistosomes.

Sinna occidentalis and Moringa oleifera are plants been used among the people for many reasons such as food, flavor, medication among the people in different part of the world. Therefore, molluscicidal efficacy these plants against intermediate host of S. haematobium (B. globosus) were evaluated to be an increment efficient, non hazardous, efficient, cheep, and available way of controlling urinary Schistosomiasis among people of Goronyo, Shagari Local Government Areas of Sokoto State, Nigeria as well as other part of world where Schistosomiasis infections are common.

\section{Methodology}

\section{A. Area of the Study}

Present studies were carried out inside the General Biology laboratory, Department of Biological Sciences, Sokoto State University, Sokoto. Sokoto was in northwestern part of Nigeria; it had common borders with Republic of Niger to the North, Kebbi state of Nigeria to the south west and Zamfara state to the east. Sokoto has people population of $3,702,676$, the vegetation is Sudan savannah, it lies within the longitude between $4^{\circ} 8^{\prime} \mathrm{E}$ and $6^{\circ} 5^{\prime} \mathrm{E}$ and latitude between $12^{\circ} 0^{\prime} \mathrm{N}$ and $13^{\circ} 54^{\prime} \mathrm{N}$. the state experience four (4) to five (5) months rainfall annually (June to September or October) and 8 to 7 months dry season (from October to may), Sokoto has relative humidity vary from 10 to $25 \%$ during dry season and 51 to $75 \%$ during the rainy season with annual average temperature of $33.2{ }^{\circ} \mathrm{C}$, the maximum daytime temperatures are generally under $40{ }^{\circ} \mathrm{C}$ most of the year, and the dryness makes the heat bearable. The warmest months are February to April, where daytime temperatures can exceed $45{ }^{\circ} \mathrm{C}$; the highest recorded temperature is $47.2^{\circ} \mathrm{C}$. The settlement areas around Sokoto have various types of fresh water bodies such as lakes and rivers [28]. B. globosus snails were collected from Shagari and Goronyo dam; both Shagari and Goronyo local governments had dam namely Shagari dam and Goronyo dam, respectively. Many people around the two dams are extremely poor and dependent on fishing and other farming activities for source of their income and nutrition; they also used water from the rivers and dams for their home activities.

\section{B. Plants Collection and Preparation of Powder}

S. occidentalis and M. oleifera leaves used for the present study were purchased from Goronyo market, Goronyo Local government, Sokoto, the plants were mounted and maintained in herbarium press then transported to herbarium for identifications and authentications, the two plants were authenticated and identified as $\mathrm{S}$. occidentalis and $\mathrm{M}$. oleifera in department of biological sciences Usmanu Danfodiyo University Sokoto and voucher number was deposited as UDU/ANS/0110 and UDUS/ANS/0225 for $S$. occidentalis and $M$. oleifera respectively. Thereafter, the 
fresh leaves of the plants were air dried under shade and grinded into powder using pestle and motor then stored in a sterilized container to avoid contamination [29].

\section{Snail Collection}

Three thousand (3000) adult snails with shall range between 11 to $13 \mathrm{~mm}$ were collected from Goronyo and Shagari dams of Goronyo and Shagari Local Governments respectively between 9:00am to 12:00 noon by using scoop which comprised wooden frame and net. The snails were brought to the General Biology Laboratory, Department of Biological Science, Sokoto State University in 25 liters bucket containing water from the source of collection; the length of the snails' shells were measured using a Veneer Caliper [30].

\section{Preparation of Extracts}

The extracts of each plant leaves were prepared using cold maceration method. Five hundred grams (500 g) of the plant was weighted and soaked in to $3000 \mathrm{ml}$ of solvent in tightly covered bottles then mixed and allowed for three days (72 hour) at $20{ }^{\circ} \mathrm{C}$, each suspension was shaken vigorously after each 24 hours. Each suspension was sieved using a mesh then filtered through a Whatmann filter paper and each of the plant filtrate was purified using column chromatography [31].

\section{E. Column Purification}

The columns were place vertically using a stand and clamp, two hundred milligram $(200 \mathrm{mg})$ of cotton wool was inserted inside the column and pushed down to prevent the escape of silica gel, $140 \mathrm{~g}$ of silica gel with 60-120 mesh was added into the column, in each purification of each extract solvent to be used was added to flush through the column and make wetted, while flushing the column, it was slapped several times to remove the air bubbles, dropping funnel was attached on top of the column, extract to be purified was poured gently in to the column, methanol, ethanol, ethyl acetate and hexane were used differently for the purification of each of the plants extract, the mobile phase was added continuously for each plant purification until the extract eluted, fractions were collected using plastic measuring cylinder, 32 fractions were collected from each plants and each of the fraction showing similar colour with one another were matched together hence, four (4) fractions were obtained and labeled as F1, F2, F3 and F4 [32].

\section{F. Identification and Maintenance of the Snails}

Identification key was used initially to identify $B$. globosus species inside General Biology laboratory, Department of Biological Sciences, Sokoto State University Sokoto as described by [33]. Afterward, identified snails were transported to Museum of Natural History; Zoology Department of Ahmadu Bello University Zaria for confirmation of the B. globosus species by Malacologist, the cabinet number assigned to the identified animals was $7 \mathrm{~B}$, then the snails were transported back to the General Biology Laboratory, Sokoto State University for molluscicidal activity study.

\section{G. Preparation of the Concentrations Used for the Toxicity Experiment}

After preparation of stock solution, concentration of each of the plant extract was obtained using serial dilution formula $\left(\mathrm{C}_{1} \mathrm{~V}_{1}=\mathrm{C}_{2} \mathrm{~V}_{2}\right)$, the final volume used was adjusted to obtained various concentration of the plant extract in milligram per liter. Therefore, $120 \mathrm{mg} / \mathrm{l}$ was prepared and used for the toxicity experiment of each fraction of each plant against $B$. globosus.

\section{H. Molluscicidal Efficacy Test}

Each of the plants extracts for $S$. occidentalis and $M$. oleifera (leaves) and their binary combination was tested for molluscicidal activity against B. globosus based on [34] guidelines procedure for molluscicidal activity test adopted by [35] with some modifications, in which ten (10) adult B. globosus were introduced into troughs containing $120 \mathrm{ppm}$ of different fractions, the experimental animals were monitored for 96 hours inside the experimental container in starve condition, treatment in each fraction was replicated five (5) times, to confirm the mortality of the experimental animal, absence of response to the needle probe was used as an indication for the snails death. Another ten snails for each treatment was immersed in separate borehole water with the same condition without treatment to serve as control. Mortality was calculated using Abbott's formula by subtracting number of survival snails in the treated group from number of survivals from the untreated group multiplied by hundred.

\section{Phytochemical Analysis}

Qualitative and quantitative phytochemicals of the plant's leaves were determined using methods described by [36][39].

\section{J. Statistical Analysis}

Mortalities were calculated using Abbott's formula, oneway Analysis of Variance (ANOBA) followed by Duncan Multiple Range Test were used to determine statistically significant differences between means $(\mathrm{P}<0.05)$ using IBMSPSS software package version 20.

\section{RESULTS}

Molluscicidal efficacy of $S$. occidentalis and $M$. oleifera singly and their combination against $B$. globosus were time and concentration dependents, the animals were observed attempting to escape from the toxicity of the extracts immediately after introducing them into experimental container of each fraction, by distressing and becoming firmly attached to the wall of experimental container then died eventually, shells of the snails also were filled up, pores were also observed on the foot of some snails and shell's color of the snails changed from brown to dark brown and mortality was recorded after 24 hour for the period of 4 days (96 hours).

\section{A. Molluscicidal Efficacy of $M$. oleifera against $B$. globosus after 96 Hours}

Fractions of methanolic leaves extracts of $M$. oleifera showed higher mortality of B. globosus [where F2 showed $92.0 \%(9.2 \pm 0.374)$ mortality, F3 caused $76.0(7.6 \pm 0.400)$ 
mortality, F1 accounted for $72.0 \%(7.6 \pm 0.200)$ mortality while F6 showed $56.0 \% \quad(5.6 \pm 0.245)$ mortality with significant difference $(\mathrm{P}=0.000)]$ followed by fractions of hexane extract [in which F2 caused $66.0 \%(6.6 \pm 0.245)$ mortality, F1 showed $56.0 \%(5.6 \pm 0.245)$, F3 with $48.0 \%$ $(4.8 \pm 0.200)$ and F4 showed $40.0 \% \quad(4.0 \pm 0.316)$ with statistical significant difference $(\mathrm{P}=0.001)]$ then ethanolic extracts [whereby F4 showed $62.0 \%(6.2 \pm 0.374)$ mortality, F3 showed $46.0 \%(4.6+0.400)$ mortality, F2 caused $40.0 \%$ (4.0+0.316) mortality while F1 showed $38.0 \%(3.8 \pm 0.374)$, however, significant difference was observed $(\mathrm{P}=0.000)$ ] and least mortality of $B$. globosus was recorded in the fractions of Ethyl acetate [whereby $54.0 \%$ (5.4 \pm 0.400$)$, $48.0 \% \quad(4.8 \pm 0.374), \quad 40.0 \% \quad(4.0 \pm 0.316)$ and $34.0 \%$ (3.4 \pm 0.400$)$ mortalities where recorded in F1, F2, F3 and F4 respectively with statistical significant difference $(\mathrm{P}=0.008)$ ] as showed in Table 1.

TABLE 1: MOLLUSCICIDAL EFFICACY OF $M$. OLEIFERA AGAINST $B$.

\begin{tabular}{|c|c|c|c|}
\hline $\begin{array}{l}\text { Fraction } \\
\text { Number }\end{array}$ & $\begin{array}{l}\text { Mean No. of } \\
\text { Died } B . \\
\text { globosus }\end{array}$ & $\begin{array}{c}\text { Values of } \\
\text { Significant at } \\
\mathbf{P} \leq \mathbf{0 . 0 5}\end{array}$ & $\begin{array}{c}\text { Mortality of } \\
\text { B. globosus } \\
(\%)\end{array}$ \\
\hline Hexane Extract & & 0.001 & \\
\hline F4 & $4.0 \pm 0.316^{\mathrm{d}}$ & & 40.0 \\
\hline F3 & $4.8 \pm 0.200^{c}$ & & 48.0 \\
\hline $\mathrm{F} 1$ & $5.6 \pm 0.245^{\mathrm{b}}$ & & 56.0 \\
\hline $\mathrm{F} 2$ & $6.6 \pm 0.245^{\mathrm{a}}$ & & 66.0 \\
\hline $\begin{array}{l}\text { Methanol } \\
\text { Extract }\end{array}$ & & 0.000 & \\
\hline $\mathrm{F} 4$ & $5.6 \pm 0.245^{\mathrm{c}}$ & & 56.0 \\
\hline $\mathrm{F} 1$ & $7.2 \pm 0.200^{\mathrm{b}}$ & & 72.0 \\
\hline F3 & $7.6 \pm 0.400^{\mathrm{b}}$ & & 76.0 \\
\hline $\mathrm{F} 2$ & $9.2 \pm 0.374^{\mathrm{a}}$ & & 92.0 \\
\hline $\begin{array}{l}\text { Ethyl acetate } \\
\text { Extract }\end{array}$ & & 0.008 & \\
\hline $\mathrm{F} 4$ & $3.4 \pm 0.400^{\mathrm{b}}$ & & 34.0 \\
\hline F3 & $4.0 \pm 0.316^{\mathrm{b}}$ & & 40.0 \\
\hline $\mathrm{F} 2$ & $4.8 \pm 0.374^{\mathrm{a}}$ & & 48.0 \\
\hline $\mathrm{F} 1$ & $5.4 \pm 0.400^{\mathrm{a}}$ & & 54.0 \\
\hline Ethanol Extract & & 0.000 & \\
\hline $\mathrm{F} 1$ & $3.8 \pm 0.374^{\mathrm{b}}$ & & 38.0 \\
\hline $\mathrm{F} 2$ & $4.0 \pm 0.316^{\mathrm{b}}$ & & 40.0 \\
\hline F3 & $4.6 \pm 0.400^{\mathrm{b}}$ & & 46.0 \\
\hline F4 & $6.2 \pm 0.374^{\mathrm{a}}$ & & 62.0 \\
\hline Control & $0.00 \pm 0.00$ & & 0.00 \\
\hline
\end{tabular}

B. Molluscicidal Efficacy of S. occidentalis against B. globosus after 96 Hours

It was observed that, fractions of hexane extracts of $S$. occidentalis were more effective for the mortality of $B$.

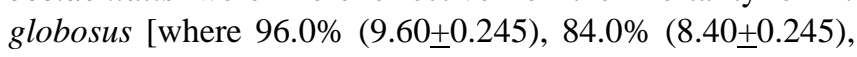
$68.0 \%(6.80 \pm 0.200)$ and $60.0 \%(6.00 \pm 0.316)$ were recorded inF4, F3, F2 and F1 respectively with statistical significant difference $(\mathrm{P}=0.000)$ ] followed by methanolic extract [in which $74.0 \% \quad(7.40 \pm 0.245), 62.0 \% \quad(6.20 \pm 0.374), 54.0 \%$ $(5.40 \pm 0.510)$ and $48.0 \%(4.80 \pm 0.374)$ mortalities were observed in F3, F4, F1 and F2 respectively with statistical significant difference $(\mathrm{P}=0.001)]$ then fractions of ethyl acetate extracts [where F4, F3, F2, F1 showed $68.0 \%$ $(6.80 \pm 0.200), 60.0 \%(6.00 \pm 0.316), 48.0 \%(4.80 \pm 0.200)$ and $42.0 \%(4.20 \pm 0.200)$ respectively with significant difference $(\mathrm{P}=0.000)]$, however, ethanolic extracts of $S$. occidentalis showed least mortalities of the snails [whereby $50.0 \%$ (5.00 \pm 0.316$), 48.0 \%(4.80 \pm 0.200), 40.0 \%(4.00 \pm 0.000)$ and
$34.0 \%(3.40 \pm 0.245)$ mortalities were observed in F4, F3, F2 and $\mathrm{F} 1$ respectively with significant difference $(\mathrm{P}=0.000)]$ (Table 2).

TABLE 2: MOLLUSCICIDAL EFFICACY OF $S$. OCCIDENTALIS AGAINST $B$.

\begin{tabular}{|c|c|c|c|}
\hline Fraction Number & $\begin{array}{l}\text { Mean No. of } \\
\text { Died } B . \\
\text { globosus }\end{array}$ & $\begin{array}{c}\text { Values of } \\
\text { Significant at } \\
\mathbf{P} \leq \mathbf{0 . 0 5}\end{array}$ & $\begin{array}{c}\text { Mortality } \\
\text { of } B . \\
\text { globosus } \\
(\%)\end{array}$ \\
\hline Ethanol extract & & 0.000 & \\
\hline $\mathrm{F} 1$ & $4.20 \pm 0.200^{\mathrm{c}}$ & & 42.0 \\
\hline $\mathrm{F} 2$ & $4.80 \pm 0.200^{c}$ & & 48.0 \\
\hline F3 & $6.00 \pm 0.316^{\mathrm{b}}$ & & 60.0 \\
\hline $\mathrm{F} 4$ & $6.80 \pm 0.200^{\mathrm{a}}$ & & 68.0 \\
\hline Hexane Extract & & 0.000 & \\
\hline $\mathrm{F} 1$ & $6.00 \pm 0.316^{\mathrm{d}}$ & & 60.0 \\
\hline $\mathrm{F} 2$ & $6.80 \pm 0.200^{\mathrm{c}}$ & & 68.0 \\
\hline F3 & $8.40 \pm 0.245^{\mathrm{b}}$ & & 87.0 \\
\hline $\mathrm{F} 4$ & $9.60 \pm 0.245^{\mathrm{a}}$ & & 96.0 \\
\hline Methanol Extract & & 0.001 & \\
\hline $\mathrm{F} 1$ & $4.80 \pm 0.374^{\mathrm{d}}$ & & 48.0 \\
\hline $\mathrm{F} 2$ & $5.40 \pm 0.510^{\mathrm{c}}$ & & 54.0 \\
\hline F3 & $6.20 \pm 0.374^{\mathrm{b}}$ & & 62.0 \\
\hline $\mathrm{F} 4$ & $7.40 \pm 0.245^{\mathrm{a}}$ & & 74.0 \\
\hline Ethyl acetate extract & & 0.000 & \\
\hline $\mathrm{F} 1$ & $3.40 \pm 0.245^{\mathrm{b}}$ & & 34.0 \\
\hline $\mathrm{F} 2$ & $4.00 \pm 0.000^{\mathrm{b}}$ & & 40.0 \\
\hline F3 & $4.80 \pm 0.200^{\mathrm{a}}$ & & 48.0 \\
\hline $\mathrm{F} 4$ & $5.00 \pm 0.316^{\mathrm{a}}$ & & 50.0 \\
\hline Control & $0.00 \pm 0.000$ & & 0.0 \\
\hline
\end{tabular}

\section{Molluscicidal Efficacy for the Combination of the Two} Plants against B. globosus after 96 Hours

After 96 hours in to various fractions of different solvents of the plants combination, it was reported that, fractions of Hexane extracts showed highest mortality of the snail [where F2 and F3 showed 100\% (10.00+0.000) mortality of the snails while F1 and F4 showed 98.0\%(9.80+0.200) and $82.0 \%(8.20 \pm 0.200)$ mortalities respectively with statistical significant difference $(\mathrm{P}=0.000)]$; followed by fractions of methanol with $100 \%(10.00 \pm 0.000), 90.0 \%$ (9.00+0.316), $76.0 \%(7.60 \pm 0.510)$ and $66.0 \%(6.60 \pm 0.245)$ mortalities in $\mathrm{F} 4, \mathrm{~F} 3, \mathrm{~F} 2$ and $\mathrm{F} 1$ respectively with significant difference $(\mathrm{P}=0.000)$; then fractions of ethyl acetate [which showed mortality of $98.0 \% \quad(9.80 \pm 0.200), \quad 78.0 \% \quad(7.80 \pm 0.200)$, $72.0 \%(7.20 \pm 0.200)$ and $64.0 \%(6.40 \pm 0.245)$ for F4, F3, F2 and $\mathrm{F} 1$ respectively with significant difference $(\mathrm{P}=0.000)$, while least mortality was reported in ethanol [where F4, F3, F2 and F1showed 96.0\% (9.60 \pm 0.245$) 84.0 \%(8.40 \pm 0.510)$, $76.0 \%(7.60 \pm 0.245)$ and $64.0 \%(6.40 \pm 0.245)$ mortality was reported respectively with significant difference $(\mathrm{P}=0.000)$ as reported in Table 3.

\section{Phytochemical Constituents of the Plants}

Phytochemical analysis of $S$. occidentalis reviled that, alkaloids, flavonoids, saponins, tannins, and glycosides were present in excess, cardiac glycosides and volatile oils were moderately present while balsams, steroids and antraqunones quietly present whereas analysis phytochemical constituents of $M$. oleifera showed excess flavonoids, saponins, glycosides and antraqunones. Although, alkaloids, volatile oils, tannins and steroids were moderately presents, balsams and cardiac glycosides were presents in least quantities while all the phytochemicals were found in excess in the combination of the two plants 
with exception of volatile oils and balsams which were found moderately present as shown in Table 4.

TABLE 3: MOLLUSCICIDAL EFFICACY FOR THE COMBINATION OF TWO PLANTS AGAINST $B$. GLOBOSUS AFTER 96 HOURS $(\mathrm{N}=10)$

\begin{tabular}{cccc}
\multicolumn{3}{c}{ PLANTS AGAINST $B$. GLOBOSUS AFTER 96 HOURS (N=10) } \\
\hline Fraction & $\begin{array}{c}\text { Mean No. of Died } \\
\text { B. globosus }\end{array}$ & $\begin{array}{c}\text { Values of } \\
\text { Significant at } \\
\text { Pumber }\end{array}$ & $\begin{array}{c}\text { Mortality } \\
\text { of } \boldsymbol{B} . \\
\text { globosus } \\
(\boldsymbol{\%})\end{array}$ \\
\hline
\end{tabular}

\begin{tabular}{lccc}
\hline $\begin{array}{l}\text { Ethyl } \\
\text { acetate } \\
\text { Extract }\end{array}$ & & 0.000 & \\
F1 & $6.40 \pm 0.245^{\mathrm{c}}$ & & \\
F2 & $7.20 \pm 0.200^{\mathrm{b}}$ & & 72.0 \\
F3 & $7.80 \pm 0.200^{\mathrm{b}}$ & & 78.0 \\
F4 & $9.80 \pm 0.200^{\mathrm{a}}$ & & 98.0 \\
Hexane & & 0.000 & \\
Extract & & & \\
F1 & $8.20 \pm 0.200^{\mathrm{b}}$ & & 82.0 \\
F2 & $9.80 \pm 0.200^{\mathrm{a}}$ & & 98.0 \\
F3 & $10.00 \pm 0.000^{\mathrm{a}}$ & & 100.0 \\
F4 & $10.00 \pm 0.000^{\mathrm{a}}$ & & 100.0 \\
Methanol & & 0.000 & \\
Extract & & & \\
F1 & $6.60 \pm 0.245^{\mathrm{d}}$ & & 66.0 \\
F2 & $7.60 \pm 0.510^{\mathrm{c}}$ & & 76.0 \\
F3 & $9.00 \pm 0.316^{\mathrm{b}}$ & & 90.0 \\
F4 & $10.00 \pm 0.000^{\mathrm{a}}$ & & 100.0 \\
Ethanol & & 0.000 & \\
extract & & & \\
F1 & $6.40 \pm 0.245^{\mathrm{c}}$ & & \\
F2 & $7.60 \pm 0.245^{\mathrm{b}}$ & & 84.0 \\
F3 & $8.40 \pm 0.510^{\mathrm{b}}$ & & 96.0 \\
F4 & $9.60 \pm 0.245^{\mathrm{a}}$ & & 0.0 \\
Control & $0.00 \pm 0.000$ & & \\
\hline
\end{tabular}

NOTE: From each of the above tables, mean numbers of the snail died were expressed as Mean \pm SEM of five replicates. Value in row with different superscript differs significantly at $\mathrm{p} \leq 0.05$ level using One Way ANOVA followed by Duncan Multiple Range Test.

$\mathrm{N}=$ Number of Bulinusglobosus inside each treatment which is ten (10).

TABLE 4: PHYTOCHEMICAL ANALYSIS OF S. OCCIDENTALIS AND $M$. OLEIFERA

\begin{tabular}{lccc}
\multicolumn{4}{c}{ OLEIFERA } \\
Phytochemical & S. occidentalis & M. oleifera & $\begin{array}{c}\text { Combination } \\
\text { of the plants }\end{array}$ \\
\hline Alkaloids & +++ & ++ & +++ \\
Flavonoids & +++ & +++ & +++ \\
Saponins & +++ & +++ & +++ \\
Tannins & +++ & ++ & +++ \\
Glycosides & +++ & +++ & +++ \\
Cardiac glycosides & ++ & + & +++ \\
Volatile oils & ++ & + & ++ \\
Balsams & + & + & ++ \\
Steroids & + & ++ & +++ \\
Antraqunones & + & ++ & +++ \\
\hline
\end{tabular}

Key:

Excess Present $=+++$

Moderate Present $=++$

Quite Present =+

\section{DISCUSSION}

Molluscicidal effect of $S$. occidentalis and M. oleifera leaves extracts singly and their combination against experimental animals were time dependents, because the higher the increase in time the higher the rate of mortality observed in the treated groups, the present finding was not contrary to the report of [40] who observed that molluscicidal toxicity of Agave filifera extract on $B$. alexandrina was time dependents, similarly [41], observed that, efficacy of Bauhinia variegate and Mimusop selengi extracts against Lymnaea acuuminata was time and concentration dependents, nevertheless, [42], observed that, molluscicidal potential of Ammivis naga and Chenopodium ambrosioides against $B$. alenxendrana were attributed due to increased time of exposure and concentration dependents. This was also supported by [43] and [44]. [45], also stated that, molluscicidal potency of $M$. oleifera leaf extracts and Momordica charantia fruits against snail Lymnaea acuminate were time and concentration dependents.

Experimental animals' distresses, changing colour and filling up of the shells as well as swelled pores on the foot of the snail were due to toxicity of the plants extracts on $B$. globosus. According to [46], the inference from these observations was that, the tissue of the cephalopodal mass had accumulated water, which caused haemorrhage at lethal concentration of the active plant extracts that caused snails' distress, filling up of the shell and pores on the foot of the snail. Nevertheless, the observation made in this study of the foot-sole surface epithelium by preventing its normal osmoregulatory function [47]. This finding was similar with the reports of [48], similarly, [48], observed movement of snails to the side of the container in an attempt to escape from the test media containing Althernan therasessils treated water. [49], also reported that, the snails showed several behavioral responses, including the "distress syndrome" described for other Planorbid species, indicative of intoxication and they stated that, swelling of the tissues was not restricted to the tentacles, but involved the whole cephalopodal mass.

Although, significant difference was observed between mean mortality of the snails treated in fractions of each plant used after 96 hours of the experimental set up, higher mortalities were recorded in combination of the plants extracts and when compared to the single forms of the two plants, the combination of the two plants had higher toxicity against B. globosus than the single form of the plants. Although this report is contrary to [50], who observed that, use of plant extracts singly, especially in the case of Sinna occidentalis is more effective than combination of two or more plants against the test organism (Lymnaea ovum) snail. It was similar to observation of [51], who reported at, the use of plant in combination, is more effective than individual plants towards snail control. Similarly, this finding was also in agreement with the work of [52] who reported that, combination of two plants showed more effectiveness in the control of Biomphalaria alexandrina. In addition, it suggested that combinations of equal parts of custard apple seed powder with oil from Cedarcedrus, Deodara Roxh, and Azctdirachta indica, was more toxic than the individual components of these plants [53]. It was observed that, powdered seed of Annona Squamosa and Lawsonia inermis were potent against Lymnaea acuminate and Indoplanorbi sexustus and combination of these plants increased higher molluscicidal potential against the animals than it single forms [54].

Phytochemical observed into tested plants could be consider as one of the major factor that caused higher mortality of the experimental animals because animals treated with the plants combination showed higher mortality while potent phytochemicals like alkaloids, flavoides, saponins, glycosides and tannins were recovered in higher amount in the combination. This was in line with the report of some researchers among which included, [55] who reported that, potency of the plants against snails were due 
to higher amount of saponins compounds, similarly, [56], observed that, higher amount of tannins, flavonoides glycosides and alkaloids caused higher molluscicidal activity against snail species.

\section{CONCLUSION AND RECOMMENDATIONS}

Fractions extracted from the combination of the plants leaves had higher molluscicidal potential against $B$. globosus snails followed by $S$. occidentalis and least molluscicidal efficacy was observed in the column purified fractions of $M$. oleifera. Phytochemicals analysis showed that, compounds that are responsible for the higher mortality of the snails were recovered in excess amount in combination of the plants followed by $S$. occidentalis then $M$. oleifera. Hence it was recommended that, the combination of these plants should be used in control of $B$. globosus and further study should be carryout to investigate the mode of action of the plants against B. globosus by conducting histological and biochemical examinations on some body parts of the experimental animals.

\section{ACKNOWLEDGMENT}

Special acknowledgment goes to Tertiary Education Trust Fund (TeTfund) of Nigeria for the sponsorship to conduct this research work through Institution Based Research (IBR), 2017 Intervention. The research team are also grateful to the efforts of Laboratory Technologist and research assistant from Department of Biological Sciences, Sokoto State University, Sokoto Nigeria, the authors appreciate the effort of Professor Kiran Singh from the Department of Biological Sciences, Usmanu Danfodiyo University Sokoto, Nigeria as well as malacologist from Museum of Natural History Department of Zoology, Ahmad Bello University, Zaria for their maximum support for the completion of this work.

\section{REFERENCES}

[1] Ishaliku, J. W., Stothad, J. C., Basanez, M. G., Mgeni, A. F. and Khamis, I. S. (2012). Prevalence of Schistosoma mansoni infection among primary school pupils in Keffi Town, Keffi Local Government Area, Nasarawa State, Nigeria. Acta Tropica, 105(1): 45 - 54.

[2] Mbata, T. I., Orji, M. U. and Oguoma, V. M. (2009). High Prevalence of Urinary Schistosomiasis in a Nigerian Community.Annal of Trophical Medicine and Parasitology. 77: 51-59.

[3] Gryseels, B., Polman, K., Clerinx, J. and Kestens, L. (2016). The distribution of Schistosoma mansoni in the Rusizi plain (Burundi). Annal Trophical Medicine and Parasitology. 82: 581-590.

[4] Garba, A., Toure, S., Dembele, R., Boisier, P., Tohon, Z., BosqueOliva, E., Koukounari, A., and Fenwick, A. (2012). Present and future schistosomiasis control activities with support from the Schistosomiasis Control Initiative in West Africa. Parasitology, 136 (13):1731-1737.

[5] Steinmann, J. Q. PauL, D. K. and Olofintoye, L.K. (2016). Comparative evaluation of molluscicidal effects of Securidacalongepedunculata(Fres) and Tephrosia brcleolata(Gulland perr) on B. globosus. Journal of Parasitology andVector Biology.2(3): 44-47.

[6] King, C. H., and Dangerfield-Cha, M. (2013). The unacknowledged impact of chronic schistosomiasis. Chronical Illiness, 4:65-79.

[7] Sprecher, N. D., and Getsinger, S. P. (2010). Biological and biochemical responses of Biomphalariaalexandrinato some extracts of the plants Solanum siniacumand Artemisia judaica L. Pesticide Biochemistry Physiology.99, 174-180.
[8] Steinmann, P., Keiser, J., Bos, R., Tanner, M., and Utzinger, J. (2012) Schistosomiasis and water resources development: systematic review, meta-analysis, and estimates of people at risk. Lancet Infectious Diseases. 6:411-25.

[9] Mbata, T. I., Orji, M. U. and Oguoma, V. M. (2009). High Prevalence of Urinary Schistosomiasis in a Nigerian Community.Annal of Trophical Medicine and Parasitology. 77: 51-59.

[10] WHO, (2012). Molluscicide screening and evaluation," Bulletin of the World Health Organization, 33:567-581.

[11] Huw, T., Brindly, P. J., MicManus, D. P., Feng, Z. and Han, Z. G. (2014). Schistosome transcriptions: new insights into the parasites and schistosomiasis. Trends of Molecular Medicine. 10: 217 - 225.

[12] WHO, (2013). The control of Schistosomiasis," Tech. Rep. 830, WHO, Geneva, Switzerland.

[13] Bustinduy, A. L., Parraga, I. M. and Thomas, C. L, (2013). Impact of poly parasitic infections on anemia and under nutrition among Kenyan children living in a Schistosoma haematobium-endemic area, American Journal of TrophicalMededcinen and Hygein. 88:433-440.

[14] Chidozie, E. U. and Daniyan, S. Y. (2014). Epidemiological survey of urinary schistosomiasis among children in selected schools: A preliminary study in Minna, Nigeria. Annual Tropical Medicine and Parasitology, 82: 569-577.

[15] Salwa, D. H., Ibrahim, W. A., Abdulhamid, A. S. (2016). Prevalence and risk factors of schistosomiasis among Hausa communities in Kano State, Nigeria. Annal of Trophical Medicine and Parasitology. 82: 581590.

[16] John, N. C, (2014). Epidemiology and transmission patterns of Schistosoma haematobium infections in central Ebonyi State, Nigeria. International journal of natural and applied sciences. 2(3): 219 - 224.

[17] Ishaliku, J. W., Stothad, J. C., Basanez, M. G., Mgeni, A. F. and Khamis, I. S.(2012). Prevalence of Schistosoma mansoni infection among primary school pupils in Keffi Town, Keffi Local Government Area, Nasarawa State, Nigeria. Acta Tropica, 105(1): 45 - 54.

[18] Mbata, T. I., Orji, M. U. and Oguoma, V. M. (2009). High Prevalence of Urinary Schistosomiasis in a Nigerian Community.Annal of Trophical Medicine and Parasitology. 77: 51-59.

[19] Federal Ministry of Health (2012). Nigeria Federal Ministry of Health. Nigeria master plan for neglected tropical disease (NTDs) 2013-2017 Available from: http://docplayer.net/2404435-Nigeria-master-plan-forneglected-tropical-diseases-ntds-.htm.

[20] Bala, A. Y., Ladan, M. U., and Mainasara, M. (2012). Prevalence and Intensity of urinary Schistosomiasis in Abarma Village, Gusau, Nigeria, Science World Journal 7(2):197-6343.

[21] Singh, K. and Muddasiru, D. (2014). Epidemiology of schistosomiasis in school aged children in some riverine areas of Sokoto, Nigeria. Journal of Public Health Epidemiology. 6(6), 197-201.

[22] Kosala, G. A. D.,Geoffrey N. G.,Pengfei C.,Donald P. M. (2015) Advances in the Diagnosis of Human SchistosomiasisClinical Microbiology Reviews cmr.asm.org (4) 939.

[23] Joshi R. (2007). Problems with the management of Golden Apple Snail, Pomaceacanaliculata: An important exotic pest of rice in Asia.In: Vreysen M.J.B., Robinson A.S., Hendrichs J. (eds) Area- Wide Control of Insect Pests. Springer, Dordrecht, 25726.

[24] Cowie RH,Hayes HA.(2012).Apple snails. In Francis RA 2012, Ed. A handbook of global freshwater species. EarthscanTaylor and Francis, Ltd. Inc., NY, USA

[25] Massaguni R, Latip SMH. (2015). Assessment of the molluscicidal properties of azadirachtin against GAS, PomaceaCanaliculata. Malaysian Joumal ofAnalytical Science 19(4), 781-789.

[26] Ismail, A. and Oke, I. A. (2012). Statistical and trend analyses of rainfall in Sokoto. International Research Journal of Engineering Science, Technology and Innovation (IRJESTI) Vol. 1(6):161-174.

[27] Sampath, K. P., Debjit, B., Biswajit, C.,and Pankaj, T. (2010). Cllium cepa: A traditional medicinal herb and its health benefits. Journal of Chemistry and Pharmaceutical Research. 2(1): 283-291.

[28] Kanchan, L., Singh, D. K. and Singh, V. K., (2012). Characterization of the molluscicidal activity of Bauhinia variegata and Mimusopselengi plant extracts against the fasciola vector Lymnaea acuminate. Review Institute of Medicine and Trophical disease. 54:3.

[29] Handa, S. S., Khanuja, S. P. S., Longo, G. and Rakesh, D. D. (2008) Extraction Technologies for Medicinal and Aromatic Plants, Italy: United Nations Industrial Development Organization and the International Centre for Science and High Technology. (1)66.

[30] Nesti, F. Sianipara, Wilmar, M., and Alice, V. (2013). Toxic activities of hexane extract and column chromatography fractions of rodent tuber plant (TyphoniumflagelliformeLodd.) on Artemia salina Indones. Journal of Agricultural Science. 14: 1: 1-6.

[31] Mofolusho, O. F. and Benson, O. (2015). Shell morphology of three medically important tropical freshwater palmonate snails from five 
sites in south western Nigeria, International Journal of zoological research. 11 (4): 140-150.

[32] World Health Organization, (1965). Molluscicide screening and evaluation. Informal meeting of investigators on molluscicide screening and evaluation held during 17-21 November 1964. Geneva.

[33] Suleiman, J., Singh, K. Bala, A. Y., Muhammad, M. T. and M. S. Yakubu (2018). Molluscicidal Potential of Column Purified Fractions of Allium cepa against Intermediate Host of Urinary Schistosomiasis (Bulinusglobosus) in Sokoto, Nigeria. Asian Journal of Research in Zoology 1(1): 1-6,45050 ISSN: 2582-466X.

[34] Trease, G. E. and Evans, W. C. (1978). A Textbook of Pharmacognosy. 11th Edn. Bailliere Tindall London. 530.

[35] El-Oley, J., Roopashree, R., Dang, R. S., Rani, T. S. and Narendra, K (1994). Antibacterial activity of antipsoriatic herbs: Cassia tora, Momordica charantia and Calendula officinalis. International Journal Applied Research in Natural Products. 1(3):20-28.

[36] Wall, M. E., M. M., Krider, C. F., Krewson, C. R., Eddy, J. J., Willaman, D. S.and Gentry, H.S. (1954). Steroidal sapogenins. VII. Survey of plants for steroidal saponins and other constituents. Journal of American Pharmcetical Association. 43: 1-7.

[37] Harbone, K. M. Debiyi, O. O. and Sofowora, F. A. (1973). Pytochemical screening of medical plants. Iloyidia, 3, 234-246.

[38] Rawi, S. M., El-Gindy, H., Haggag, A. M., Elhassan, A. A. and Kader, A. A. (2011). New possible molluscicides from Calendula micrantha officinalisandAmmi majusplants. Physicological effect on BiomphalariaalexandrinaandBulinustruncatus. Journal of Egyptian Geritatrics Society Zoology. 16, 69-75.

[39] Kanchan, L., Singh, D. K. and Singh, V. K., (2012). Characterization of the molluscicidal activity of Bauhinia variegata and Mimusopselengi plant extracts against the fasciola vector Lymnaea acuminate. Review Institute of Medicine and Trophical disease. 54:3.

[40] Fayez, A., Bakry, K., Salwa, A. Hamdi, H. (2006). Themolluscicidal activity of some plant extracts against Biomphalaria alexandrina snails. Egytian Journal of Experimental Biology. 2: 99 - 106.

[41] Rawi, S. M., Al-Hazmi, M. and Al Nassr, F. (2000). Comparative Study of the Molluscicidal Activity of Some Plant Extracts on the Snail Vector of Schistosoma mansoni, Biomphalariaalexandrina. International Journal of Zoological Research. 7: 169-189.

[42] Abdel Kader, A., Hamdi, S. A., and Rawi, S. M. (2015). Biological and biochemical studies on Biomphalariaalexandrina snails, treated with low concentrations of certain molluscicides (synthetic and of plant origin). Journal of the Egyptian Society of Parasitolology, 35: 841-858.

[43] Aparna, U., Vinay, K. S, and Dinesh K. S. (2013). Characterization of molluscicidal component of Moringa oleifera leaf and Momordica charantia fruits and their modes of action in snail Lymnaea acuminate.Review institute of medical and trophic Sao Paulo, 55(4):251-259.

[44] Brackenbury, T. D. and Appleton, C. C., (1999) "Structural damage to the foot-sole epithelium of Bulinus africanus following exposure to plant molluscicides. Malacologia, (41)2, 393-401.

[45] Agrahari, P., Singh, V. K. and Singh, D. K. (2012). Toxicity of snail attractant pellets containing eugenol with respect to abiotic factors against the vector snail Lymnaea acuminata. Biological Agriculture and Horticulture, 28: 156-166.

[46] Azare, B. A., Okwute, S. K. and Kela, S. L. (2007). Molluscicidal activity of crude water leaf extracts of Alternanthera sesselison Bulinus(Phy) globosus. African Journal of Biotechnology. 6(4):441444.

[47] Gehad, T., El-Sherbini, R. Zayed, A. and Eman, T. (2009). Molluscicidal Activity of Some Solanum Species Extracts against the Snail Biomphalariaalexandrina. Journal of Parasitology Research. 511.

[48] Usman, A. M., and Shinkafi, S. A. (2016). Molluscicidal Activity of Some Selected Plants on Fresh water Snail Lanistes ovum. Sokoto Journal of Medical Laboratory Science. 2:149 - 156.

[49] Chauhan, S. and Singh, A. (2011). Molluscicidal potential of Lantana indica and Alstoniascholaris plants against freshwater snails Lymneaacuminita. Journal of Applied science. (06) 51-57.

[50] Akinpelu, L., Rutz, L., Valls, M. E. and Gabon, D., (2012). The global status of Schistosomiasis and its control using different plants extracts. Acta Tropica. 77(1): 45-51.

[51] Amrita, S., and Singh, D. K. (2001). Molluscicidal Activity of the Custard Apple (Annona squamosa L.) Alone and in Combination with Other Plant Derived Molluscicides. Journal of Herbs Spices and Medicinal Plants. 8(1):23-29.

[52] Singh, D. K. and Singh, V. K. (2010). Molluscicides from common medicinal plants of eastern of Uttar Pradesh. Indian Journal of Applied Toxicology. 30: 1-7.
[53] Singh, V. K. and Singh, D. K., (1995). Characterization of Allicin, as a molluscicidal agent in Allium sativum (garlic). Journal of Biological and Agricultural Horticulture, 12:119.

[54] Clisiane, C. S., Silvan, S. A., André, L. M. S., Elis, C. V. A., Antônio, S. D., Nicole P. D., Deisylaine, M. S., Matheus, I. S., and Karlos, A.L.R. (2014). Evaluation of the toxicity and molluscicidal and larvicidal activities of Schinopsisbrasiliensis stem bark extract and its fractions. RevistaBrasileiradeFarmacognosia, 24,298-303.

[55] Babeet S. T, and Rekha, V. (2010). Phytochemical evaluation and molluscicidal activity of Andrographis paniculata. Acta Tropica. 56: 4.

[56] Agrahari, P., Singh, V. K. and Singh, D. K. (2012). Toxicity of snail attractant pellets containing eugenol with respect to abiotic factors against the vector snail Lymnaea acuminata. Biological Agriculture and Horticulture, 28: 156-166.

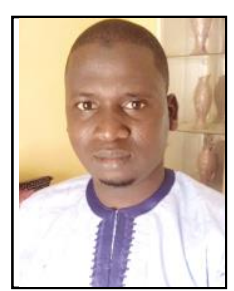

Suleiman, Jafaru from Sabon-Birni Local Government, Sokoto State, Nigeria, was born on 18 July, 1986.He obtained first degree [B. SC. (HONS.) BIOLOGY] and second degree [M. SC. ZOOLOGY (Parasitology)] from Department of Biological Sciences, Usmanu Danfodiyo, University Sokoto, Nigeria in the year 2011 and 2018 respectively.

$\mathrm{He}$ is currently Lecturer and researcher in the Department of Biological Sciences, Sokoto State University, Sokoto, Nigeria.

Mr. Suleiman attended many conferences, presented seminars and published many research articles related to prevalence, prevention and control of parasitic diseases.

Finally he is interested in teaching and research with experts in the field of Biological Sciences.

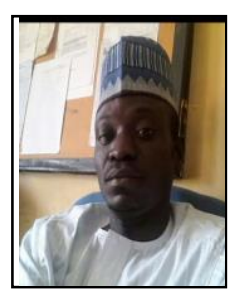

Muhammad, Musa Tanko from Sifawa, Bodinga Local Government Area of Sokoto State, Nigeria. He obtained his first degree (B. Sc. HONS) in Biology and Masters degree also in Biology all from Usmanu Danfodiyo University, Sokoto between 2009 and 2014 respectively.

He is currently Teaching and conducting researche in the Department of Biological Sciences, Sokoto State University, Sokoto, Nigeria.

Mr. Muhammad published many articles related to Plants Pathology and Plants Physiology. He is interested in teaching and conducting research with expert in Plants Physiology.

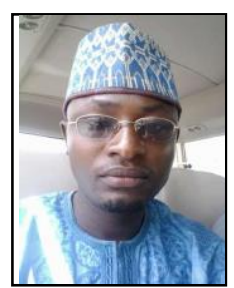

Sani, Yahaya Lema obtained his first degree (B. EDU. BIOLOGY) from Department of Science Education and Extension Services, Usmanu Danfodiyo University Sokoto. He also obtained second degree [MSC. ZOOLOLY (Parasitology)] from Department of Biological Sciences, Usmanu Danfodiyo University Sokoto in the year 2018.

Mr. Sani who is lecturer and researcher was also pioneer Head of Department, Department of Biological Sciences, Sokoto State University, Sokoto. He had focused on teaching and research in which he published many research articles in the field of Zoology particularly Parasitology and entomology.

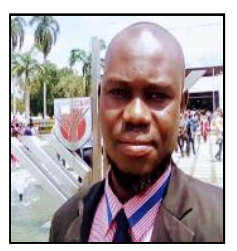

Adamu, Abdullahi from Gada Local Government, Sokoto State, Nigeria, born on 08 July, 1983. He obtained first degree [B. SC. (HONS.) BOTANY] and second degree [M. SC. BOTANY (Plant pathology)] from Usmanu Danfodiyo, University Sokoto, Nigeria by the year 2008 and 2013 respectively. $\mathrm{He}$ is currently pursuing $\mathrm{PhD}$ programme in the department of plant protection, faculty of agriculture at university Putra Malaysia.

$\mathrm{He}$ is a lecturer and researcher in the Department of Biological Sciences, Sokoto State University, Sokoto, Nigeria. Mr. Adamu attended conferences and published articles related to identification and bio-control of plant diseases.

Finally, he is interested in teaching and research with experts in the field of Biological Sciences. 